\title{
EFFECT OF LEADERSHIP, PROFESSIONALISM APPARATUS, INFORMATION TECHNOLOGY AND BUDGETING PROGRAM EFFECTIVENESS OF DIRECTORATE GENERAL OF SMALL AND MEDIUM MINISTRY OF INDUSTRY
}

\author{
Yurisman Star \\ Ph.D Student at University of Satyagama, Jakarta, Indonesia \\ Email : star1_bintang@yahoo.co.id
}

\begin{abstract}
This study investigates the effect on leadership,Professionalism Apparatus, and availability of Information Technology and Budgeting fairly on Directorate General of Small and Medium Enterprises of the Ministry of Industryin accordance with the need to improve the effectiveness of program development and growth of SMEs.To determine whether these independent variables influencing dependent variables Program Effectiveness either partially or simultaneously. Data collection techniques using questionnaires and literature study, data collected were tabulated and analyzed using Statistical Package for the Social Sciences (SPSS) devices and computer aids. The data analysis focused on the validity, reliability, normality test, multi collinearity, double correlation $\mathrm{F}$ test and $\mathrm{t}$ test. The Result of research showed that 69\% Leadership influences the apparatus professionalism and $75.20 \%$ there are significant Information Technology $17.70 \%$, and there are significant budgeting to Program effectiveness of $8.20 \%$. The results of this study are expected to provide an indication that respondents tend to think positively to the statement which is designed in the form of a questionnaire, it shows the programs that are presented for the development and growth of Small and medium enterprise effectively.
\end{abstract}

Keywords: Leadership, Professionalism Apparatus, Information Technology, of the Effectiveness Program Budgeting

\section{Introduction}

Directorate General of Small and Medium Enterprises (DG SME) has the task of organizing the formulation and implementation of policies in the field of development and empowerment, industrial standardization and technology industries, increased competitiveness, growth of entrepreneurship, strengthening institutional capacity, providing facilities, as well as the promotion of industrial and service industry in small industry and secondary industry agro, chemical, goods non-metal quarrying, textiles and miscellaneous, metals, machinery, transportation, maritime, as well as electronics and telematics. Director General of SME,Euis Saedah (2012) said the strategy of implementing policies drawn up leading to the vision and mission of the Directorate General of SME. Bambang (2009: 25) vision and mission of the Directorate General of SMEs in line with the statement of the functions of government are (1) to be educated and lead, (2) understand the aspirations of a growing, (3) as a catalyst and a dynamic, (4) sensitive to the environment and (5) make the policy as outlined in the regulations.

Director General of SME together with his staff echelon II, III and echelon IV formulate a road map (guide) through strategic planning with the preparation of the programs 
based on performance in the realization of key performance indicators (KPIs). The programs are drawn up based on performance is expected to realize the realization of KPI ratio of the number of SMEs in Java and outside Java 60: 40 of the previous 70\%: 30\% and increase the GDP contribution of SMEs to GDP the industry from $30 \%$ to $34 \%$ at year-end 2014. the action plan of the program realized in the form of clusterdevelopment is the mandate of Presidential Decree No. 28 of 2008 on the National Industrial Policy. In the regulation 5 (five) commodities SMEs to development, namely: Snacks, Essential Oils, Pottery / Ceramics, Decorative, Gems and Jewelry, and Salt People. While in the facilitation of the implementation of program activities, the Directorate General of SME guided by policy outlined in the strategic plan, namely the industrial cluster approach, OVOP and entrepreneurship as well as support programs and support.

To identify the effectiveness of the implementation of the program development and growth of SMEs carried out an evaluation based on the guidelines evaluation of performance accountability of government agencies (Ministerial Decree, No. 25 of 2012). In Article 4, paragraph 3 states that an overview of the results of evaluation of performance accountability of internal organizational units, annually reported to the Minister of Administrative Reform and Bureaucratic Reform cq Deputy Administrative Oversight and Accountability later than the end of September.

Thus, the Directorate General of SME Leadership environment as the leader can redirect and improve professionalism Apparatus to facilitate the task and work as civil servants, setting up of Information Technology infrastructure and Budgeting support programs according to need. This condition can describe the level of achievement of the implementation of the Effective Program Effectiveness affect the achievement of KPIs DG SMEs and SME products with high competitiveness. Here the author tries to present the condition of Leadership, Professionalism Apparatus, Information Technology and Budgeting and Program Effectiveness Directorate SME development and growth of SMEs.

On the basis of the research in the Directorate General of SME with the title:"Influence of Leadership, Professionalism Apparatus, Information Technology and Budgeting The Effectiveness Program of the Directorate General of Small and Medium Enterprises of the Ministry of Industry", where the purpose of the study to analyze the influence of leadership, professionalism of personnel, information technology and budgeting partially or jointly against Effectiveness Program Directorate General of Small and Medium Industry of the Ministry of Industry.

The benefits of this research are expected to provide input material is best for the Directorate General of SME Ministry of Industry, to realize the program of work, more effective, and provide input to the Ministry Perindustsrian and DG SMEs in formulating policies that involve the apparatus to enhance the program's effectiveness through leadership, professionalism of personnel, information technology and budgeting.

\section{Literature Review}

\section{Leadership}

Randall's. Schuler and Susan E. Jackson (1996: 327) said that the leader sets the example, openness, commitment for the success of others, wishes to acknowledge the contributions. Responsibility, cooperation and trust and should lead others to emulate. Cary Yukl (2005: 13-16) confirms the characteristics of the leader visits of approach (1) leadership traits associated with motivation, personality, values and skills, (2) a behavioral approach with regard to the use of time and responsibilities, ability to solve the problem and overcome the limitations, (3) the 
influence approach relates to its ability to influence fellow workers and other people around the working environment, (4) the situational approach with regard to the nature of a subordinate, the type of responsibility and the nature of the external environment,

According Karjadi (1989: 17) there are various theories on Leadership, among others: Theory Talent, that leadership begins from individual talent, but the talent has to be developed to train themselves in nature and certain habits with reference to a theory of mental attitude must be owned by a leader. Leadership is supported with specific competences. According to Gibson et al (1995: 11) that the competencies that must be owned by a leader meets at least three (3) of the following elements: intelligence, surveillance ability, personality and physical character ". In the opinion Utomo and Abidin (1998: 92) the requirements that must be met by a leader is physical vitality and stamina, intelligence and wisdom, a sense of great responsibility, high spirits to achieve success, aspirational,

\section{Apparatus professionalism}

Apparatus of professionalism able to respond to global developments and aspirations of the people, especially of SMEs by promoting the values of service that is responsive, innovative, effective, which refers to the vision and mission that has been set. According Ancok (1999) based on the professionalism measurement adaptability, ability to adapt to a global phenomenon and a national phenomenon. Professionalism in view Korten and Alfonso (1981) measured through the expertise of individuals in accordance with the tasks assigned to them will have a positive impact for the institution. According Siagian (2000) professionalism is measured in terms of speed in carrying out the functions and refers to procedures established views of several things: creativity, innovation, and responsiveness.

According Lenvine et.al is the responsiveness is the ability of organizations to identify community needs, sets the agenda and priorities of service, and develop public service programs according to the needs and aspirations of the public. Further illustrated by Dwiyanto (1995: 7) that the responsiveness relating to compatibility and harmony between the program and service activities with the needs and aspirations of the community. According Solihin (2007) Indicators for measuring a minimum of professionalism is high Performance; Be consistent; Creative and innovative; Have qualified in the field. While the support device is a standard indicator of competence in accordance with its function; Professional ethics; Reward and punishment system that is clear; System development of human resources (HR); Standards and performance indicators.

\section{TechnologyInformation}

Application of Information Technology in SMEs is to support all activities related to the information. DG HPI uses a network of on-line information system between government agencies at both central and local SMEs can access all data and information related SMEs to public service. The use of this information technology encourage government officials to work more efficiently with high productivity, resulting in improved services towards the realization of good government (good govermance).

William and Sawyar (2005) provide a more comprehensive definition, information technology is a general term that describes a variety of technologies that help production, storage, and communication or dissemination of information. Information technology is the result of human engineering to the process of delivering information from the sender to the receiver so that the delivery of such information will be faster, more widespread, and longer 
storage. In the Law of Information and Electronic transactions of the Republic of Indonesia Number 11 Year 2008 Article 1, paragraph 3 is an information technology is a technique to collect, prepare, store, process, publish, analyze, and / or disseminate information.

Application software in SME companies can trade electronically or so-called ecommerce. E-Commerce is a trade or transaction using the internet communications network will greatly assist the development of SMEs, since such acceptance and delivery of technology and market information among SMEs can be done within an indefinite period. It could be argued, including online information technology management system in the company.

\section{Budgeting}

DG SMEs in the period 2010-2014 compiled Budgetting based on performance (performance-based budgeting). The programs that have been assigned a budget is implemented in accordance with the available budget allocations and expenditures exceeding the ceiling limit. Annual budgeting predetermined describe the activities of each program Directorate of Region 1, Region 2 Directorate, Directorate of Region 3 and the General Secretariat. The programs organized by the Directorate General SME policy contained in the strategic plan 2010-2014. As for policy development and growth of SMEs is carried outApproach One Village One Product (One Village One Product - OVOP) that its operation is based on the Ministerial Decree No. 78 / M.IND / PER / 9/2007 and cluster approachthat its operation is based on the National Industrial Policy Presidential Regulation No. 28 Year 2008.

Robinson and Brumby (2005), budgetingis a performance-based procedures and mechanisms to strengthen the link between the budget provided by the goals or objectives to be achieved. Robinson and Last (2009), suggestsbudgetingperformance-based aims to improve the efficiency and effectiveness of public expenditure by linking the funding of public sector organizations with the results achieved systematically. The proposed program budgeting DG SMEs accounted for the rulinggovernment. Furthermore Carlin (2004), expressed in the public sector, performance indicators should assist users in budgetary expenditure classification according to the object details shopping with accountability provisions governmentthe good one.

Therefore, budgetingbased on performance is a systematic approach to budgeting that links expenditures to public sector organizations with the resulting performance. This implies a strict control on the input that resulted in a lack of flexibility for managers (the budget) in the use of its budget. According to Bastian (2006), planning and good management practice in budget expenditures by budget users, output indicators could be the basis for assessing the progress of an activity is associated with measurable targets with good activity. Diamond (2005), confirms the achievement of performance should reflect the goals and priorities government, The target can be measured (measurable desired results) are expressed in terms of output or outcome.

Implementation of performance-based budgeting in government agencies has been initiated by the enactment of Law No. 17 Year 2003 on State Finance and is applied gradually starting fiscal year 2005. The government has issued Government Regulation No. 20/2004 on the Government Work Plan (RKP) and the Regulation No. 21/2004 concerning Preparation of Work Plan and Budget Ministry/Agency (PWP-MA ) as the operational of the performance budgeting policy. In fact, the Ministry of Finance has set up a more detailed implementation of performance budgeting in the Minister of Finance No. 54 / PMK.02 / 2005 and built a computer program application PWP-MA.

Performance-based budgeting is a system of planning, budgeting and evaluation that emphasizes the linkages between the budget with the desired result. The implementation of 
performance budgeting should start with the planning of performance, both at the national level (government) and the level of the agency (ministry/agency), which contains a commitment on the performance that will be produced, translated in programs and activities that will be carried out.

\section{Effectiveness Program}

Programs of development and growth of SMEs in achieving KPIs stated in the strategic plan of the Directorate General of SME Year 2010-2014. The program is a collection of concrete activities, systematic and integrated carried out by one or more government agencies or in the framework of cooperation with the community, or who are active community participation, in order to achieve the goals and objectives that have been set. Towards EuisSaedah as aDirector General ESM, said there were 10 (ten) development program for SMEs is a priority in its development ie.

1) Incentivize major industry involving SMEs in industry value chain

2) Improvement of SME access to financing, including facilitation of the establishment of joint financing (venture capital) ESM.

3) Penuumbuhan forces together to form a collective force to create economies of scale through standardization, procurement and marketing together.

4) Protection and facilitation of new innovations to simplify the management of intellectual property rights for SMEs created new creations.

5) Dissemination of information and facilitation of sale and marketing in the domestic and export markets.

6) Enforced policy biases that inhibit and reduce the competitiveness of the small industries.

7) An institutional capacity SME centers and centers of creative industries, as well as UPT, TPL, and SME consultants.

8) Strengthening institutional cooperation with educational institutions, and research and development;

9) Strengthening institutional cooperation with chambers of commerce and industry and / or industry associations, and professional associations; and

10) Provision of facilities for SMEs

\section{Leadership, Professionalism Apparatus, Application Technology and Penganggaran together against effective Program}

Growth and development of small and medium enterprises (SMEs) should be accelerated suppose that the nature of leadership, professionalism Apparatus, Information Technology and Budgetting together against program efectivity is executed proportionally. EuisSaedah (2013) Director General of SME recalls fostering SME growth and development of SMEs DG consists of.

1) SME product development is done through guidance to design, develop and launch a product that is competitive in domestic and foreign markets.

2) Development of SME products made in certain centers where a group of SME companies that produce similar products, using raw materials of similar or do the same workmanship that can be strengthened through the development of human resources capacity, technology development, expansion and development of market information centers. 
3) Development of entrepreneurship to grow and develop new entrepreneurs SMEentrepreneur in charge imbalance between the Java and the outer as well as strengthening the entrepreneurial skills of SMEs.

4) Treatment restructuring SMEs with replacement machines and equipment or the addition of machinery / equipment is more advanced, efficient and productive to produce quality products.

5) Regulation of the Minister of Industry No. 142 / M-IND / PER / 10/2009 on Guidelines for the management of TSU SMI, Technical Services Unit (TSU) SME is a work unit is professionally managed with the principle of non-profit has the duty and function of providing services to the company or the perpetrators of SMEs in order to develop and the development of SMEs, including printing businesses or new entrepreneurs and

6) Poverty alleviation through employment expansion and produce goods and / or services industries.

Essentially these programs can be run properly achieve the purpose of the program is planned.

1) Leadership is a very important factor to achieve the purpose of the program is planned. The leader is responsible for the growth and development of SMEs.

2) Apparatus professionalism that have experience, behaviors, and skills that effectively have the dedication and motivation in the growth and development of SMEs.

3) Information technology with a complete infrastructure and operated by personnel with high competence in the field of information technology promote the growth and development of SMEs.

4) Budgeting programs that encourage coaches prepared to provide guidance to properly follow the standard procedure. RachmatHidayat et al (2014) said builder is one of the most dominant factor in determining the success of achieving the success of a program, because the aspect of availability of funds was instrumental to ensure the passage of all the activities of the organization.

\section{Research Methods}

This study used quantitative explanatory approaches. The methods used to collect the data is by undertaking field observation, interview and by distributing questionnaires to the sample respondents. In addition to the above primaries of data, the secondary Data were collected by using a Web search and other relevant literature. The sample was chosen by applying a proportional stratified random sampling technique. The number of samples collected using the formula Slovin was 350 respondents. Reviews These respondents include the staff ofDirectorate General of SME, The Data collected was then analysed by using the multiple regression analysis. The variables under-estimation is the effectiveness of the program as the dependent variable (Y), while the independent variables are Leadership (X1), Variable Professionalism Apparatus (X2), Variable Information Technology (X3) and Variable Budgeting (X4). The models statistically can be written as:

$$
\mathrm{Y}=\mathrm{a}+\mathrm{b} 1+\mathrm{b} 2 \mathrm{X} 1 \mathrm{X} 3 \mathrm{X} 2+\mathrm{b} 3+\mathrm{b} 4 \mathrm{X} 4+\mathrm{e} .
$$

Where $\mathrm{Y}=$ the effectiveness of the program

$\mathrm{X} 1$ = leadership

$\mathrm{X} 2$ = professionalisme apparatus 
$\mathrm{X} 3$ = Information technology

$\mathrm{X} 4$ = Budgeting

$\mathrm{a}=$ intercept

b1 ... b4 = coefficients

$\mathrm{e}=$ error terms

\section{Finding And Discussions}

The formulation of research implications emphasizes the effort to increase the influence of Leadership (X1), Apparatus Professionalism (X2), Information Technology (X3) and Budgeting (X4) variables so that the Program Effectiveness (Y) variable can increase. The data processed in this study were obtained from respondents' perception statements from environmental employees of the Directorate General of Small and Medium Enterprises in the Ministry of Industry. The data set is analyzed carefully using the SPSS method and computer aids. The results of the study provide clear information on the statements of each hypothesis, namely:

1) First Hypothesis

H1: There is a large influence of Leadership on the Effectiveness of the Development and

Growth Program of IKM DG-SMI received.

2) Hypothesis Two

H2: There is a large influence of Apparatus Professionalism on the Effectiveness of the

Development and Growth Program of IKM DG-SMI received

3) Third Hypothesis

H3: There is a large influence of Information Technology on the Effectiveness of

Development and Growth Programs for SMIs received by the Directorate General of SMEs.

4) Fourth Hypothesis

H4: There is a large influence of Budgeting on the Effectiveness of the Development and

Growth Program of IKM DG-SMI is accepted.

5) Fifth Hypothesis

H5: There is a large influence of Leadership, Apparatus Professionalism, Information Technology and Budgeting jointly on the Effectiveness of the Development and Growth Program of the Directorate General of IKM received.

Based on the answers and inspiration of respondents in the Directorate General of IKM environment the Ministry of Industry gave a positive statement and supported the development and growth of the Directorate General of SMEs through their respective roles. It can be seen that the enthusiasm of staff, section heads, sub-director heads and directors within the Directorate General of Small and Medium Enterprises plays an active role in preparing the planning, programming and implementation of program activities.

A trustworthy leadership that has extensive knowledge, is responsible and able to communicate, so that motivates employees to jointly carry out activities to improve the performance of DG-SMI. For this reason, leaders within the Directorate General of Small and Medium Enterprises must know the vision, mission and programs that are prepared, being implemented and will be carried out.

Professionalism Apparatus who have competence in their fields and placed in the right place so that the performance of the Directorate General of Small and Medium Enterprises can 
improve. Professionalism Apparatus has a high ability in working to follow the applicable methods in accordance with their respective fields of work will be able to improve individual performance and influence the effectiveness of the development and growth program of IKM Directorate General of IKM. in the required field. This must be done continuously.

Mastery of Information Technology has a strong influence on the effectiveness of the development and growth program of IKM DG-SMI. Information Technology in its implementation is accompanied by skilled human resources and complete set of facilities. Information Technology provides the benefits of facilitating the completion of work, extending cooperation relationships between regions and the center in developing the IKM Mastery of Information Technology processes information and can make decisions quickly and accurately.

Budgeting that is sufficient in accordance with the needs indicates that the effectiveness of the IKM IKM development and growth program can be optimally achieved. Budgeting is an important part, mainly related to HR competencies and in encouraging economic growth through the development and growth of SMEs. Budgeting support that is sufficient in accordance with needs is needed, because the implementation of program activities is carried out by supervisors who have high dedication.

The allocation of funds for the development and growth of SMIs sourced from the state budget whose implementation refers to Law No. 17 of 2003 concerning State Finance and Law No. 1 of 2004 concerning State Treasury. The use of these funds is contained in the Directorate General of Small and Medium Enterprises Strategic Plan by presenting programs that are based on performance in the context of the realization of key performance indicators (IKU). Programs based on performance are expected to be able to realize the IKU ratio of the number of SMIs in Java and outside Java 60: 40 from 70\%: $30 \%$ and an increase in the contribution of GDP IKM to industrial GDP from 30\% to 34\% at the end of the year 2014.

The target ratio is getting good leadership support, Apparatus Professionalism with competent HR in their fields, facilities and targets of Information Technology and Budgeting that is sufficient in accordance with the needs, so that the intended target can be achieved. Law of the Republic of Indonesia Number 3 of 2014 concerning Industry promulgated in Jakarta on January 15, 2014 The Minister of Law and Human Rights of the Republic of Indonesia, which in Chapter VIII stated the empowerment of Small Industries and Medium Industries. IKM development is carried out effectively and efficiently in synergy with relevant government agencies, the private sector and the wider community.

Therefore, the Directorate General of Small and Medium Enterprises facilitates SME entrepreneurs in the procurement of machinery and equipment, improved HR skills and encourages SME industry entrepreneurs to produce quality and competitive products. The Director General of IKM carries out monitoring of the development and growth of the IKM as an evaluation of the extent to which the performance of the Directorate General of IKM has been achieved, so that the development assistance activities or fields need to be identified.

Although the mechanism of development and growth of SMIs has been carried out according to the applicable policy principles, but it can happen in this study that has not yet given results in accordance with the facts of the field. Researchers in conducting research feel there are still limitations in determining respondents, because the questionnaire has not reached all employees within the Directorate General of Small and Medium Enterprises. It is expected that in other similar studies, respondents can provide statements based on facts and avoid perceptions so that research results have high objectivity. 
This study found that there is a $69 \%$ Leadership influences, influences of Apparatus professionalism $75.20 \%$ there are significant Information Technology $17.70 \%$, and there are significant budgeting to effectiveness Program of $8.20 \%$. This can be seen from: (1) the importance of leadership in providing guidance, direction and motivation so that the effectiveness of the program to be good / increases, (2) support of the leadership, infrastructure is available for conducting coaching jobs submitted in accordance with the profession owned, so the programs can be implemented effectively, (3) the role of Information Technology has to be a priority forfacilities availabilityand infrastructure as needed, so as to make a coaching service as outlined in the program to be more effective and efficient, and (4) the approach is less performance-based programming, strategic planning, and program priorities, resulting in less support successful achievement of program Effectiveness SME development and growth of the Directorate General of SME.

The above findings suggest that the Directorate General of SMEs already have to put the right leadership based on the career level and formal provisions applicable, put professionalism Apparatus according to their competence, in the Information Technology Communication included so that the constructor and SME employers are able to access the information. Refers to the achievement of performance budgeting, strategic planning, and program priorities DG or SMEs. Improved professionalism Apparatus through technical research, improving the competence through continuing education, and training regarding to their needs. The need for infrastructure to support the flow of information in order to reach the wider community as well as carry out repairing transparent budgeting system.

\section{Conclusion}

This study found that there is an influence of Leadership at $69 \%$, the influence of Apparatus Professionalism $75.20 \%$, the influence of Information Technology $17.70 \%$, and there is an effect of Budgeting on the Program Effectiveness of $8.20 \%$. This can be seen from: (1) the importance of leadership in providing coaching, direction and motivation so that the effectiveness of the program can be better or increased, (2) Support from the leadership, infrastructure available to conduct coaching, tasks given in accordance with the profession, so programs can be implemented effectively, (3) the role of Information Technology must be a priority for the availability of facilities and infrastructure in accordance with needs, so as to make the guidance services outlined in the program become more effective and efficient, and (4) the approach to programming is still limited in terms of performance, strategic planning, and priority programs, so it does not support the success in achieving the effectiveness of the development and growth program in the Directorate General of SMEs.

The findings above suggest that the Directorate General of Small and Medium Enterprises must place the right leaders based on career paths and the formal provisions that apply, and place Apparatus Professionalism in accordance with their competencies, in matters relating to information technology, including communication so that the instructors and entrepreneurs of IKM can mutually access information. Budgeting refers to the achievement of performance, strategic planning, and / or priority programs of the Directorate General of SMEs. Increased Apparatus Professionalism through technical research, increased competence through further education, and training as needed. The need for facilities and infrastructure that can support the smooth flow of information in order to reach the wider community and make improvements to a transparent budgeting system, so that it can support the effectiveness of the development and growth program at the Directorate General of SMEs. 
Vol-3, Issue-4, 2019 (IJEBAR)

E-ISSN: 2614-1280 P-ISSN 2622-4771

http://jurnal.stie-aas.ac.id/index.php/IJEBAR

\section{References}

Agus Prianto. 2009. Many Variables Influencing Effectiveness of Training and Education, Economic Education Program STKIP-PGRI Jombang, Application Management Journal, Volume 7, Number 2, May 2009

AgungKurniawan. 2005. Transforming Public Services. Yogyakarta. Updates Publisher.

Arief Dwi Sulistya. Profesionalism 2008. Government Apparatus, Diponegoro University Program: Master of Administrative Sciences

Aslichati L, Prasetyo B, Irawan P. 2010. Social Research Methods. Open University: Jakarta.

AdyaAtepBarata. 2003. Fundamentals Excellent Service, Jakarta: PT.Elek Media Komputindo.

BambangIstianto. 2009. Government Management in the Perspective of Public Service, Jakarta: STIAMI \& Partners Media Wajana.

Cary Yukl. 2005. Leadership in Organization, Jakarta: The fifth edition, PT. Index. Diana. 2001. Total Quality Management, Andi Offset, Yogyakarta.

DuwiPriyatno. 2013. Learn Faster with SPSS Statistics Sports, Publisher Andi Offset Jakarta Pusat 10540

EuisSaedah. 2013. Working Meeting of the Ministry of Industry, the Director General of the Small and Medium Industry Working Meeting of the Ministry of Industry, Jakarta.

Fraenkel, JR and Wellen, NE 2008. How to Design and Evaluate research in education. New York: McGraw-Hill.

Ghozali, Imam. 2012, Multivariate Analysis Applications with IBM Program APSS 20Semarang: Diponegoro Publisher Agency

, 2011. Multivariate analysis applications with IBM Program APSS 19, Semarang: 5th Edition Publishers Agency Diponegoro University.

.2009, Applications Multivariate Analysis with SPSS, Molds to IV, Semarang: Diponegoro Publisher Agency

Indrajit, RE (2002). Electronic Government Development Strategy and Development of Digital Technology-Based Public Services, Andi Yogyakarta.

Iqbal Hasan. 2002. Principles of Materials Research Methods and Application, First edition, Ghalia Indonesia, Jakarta. 2002. Principles of statistical material 2 (intensive statistical). Jakarta: Earth Literacy 
Vol-3, Issue-4, 2019 (IJEBAR)

\section{E-ISSN: 2614-1280 P-ISSN 2622-4771}

http://jurnal.stie-aas.ac.id/index.php/IJEBAR

Lackey MarijanKacungMarijan. 2005. Developing Small and Medium Industries Through the Cluster Approach.INSAN Vol. 7 No. 3 December 2005

Kartini Kartono 2004, Leaders and Leadership, Jakarta: PT. King Grafindo

Kartono Kartini. 2005. Leaders and Leadership, Jakarta: PT. King Grafindo

Kazuhisa Matsui. 2007. Movement of One Village One Product (OVOP) - A Regional Revitalization Efforts in Japan. PSKMP-UNHAS / IDE-JETRO

Nature faith Satoto, 2008. Application of Information Technology for Local Governments, Scientific journal Science Field engineering ENGINEERING, Vol. 29, no. 3, pp. 184-188, ISSN 0852-1697, Electrical Engineering Faculty of Engineering.

Koswara E. 2003. Theory of Local Government, Jakarta: IIP Press.

Nugraha Setiawan. 2005. Statistics nonparametric (collection of lectures), Bandung: Faculty of Animal Husbandry, Padjadjaran University.

Michael E Porter. 1994. Competitive Advantage, Jakarta: Binarupa Script

Pamudji E. 2002. Government Studies, Jakarta: IIP Press.

RachmatHidayat and SabarudinAkhmad. 2014 Faculty of Engineering, Department of Industrial Engineering, University Trunojoyo Jl. RayaTelang, PO BOX Kamal Bangkalan, Journal of Industrial Systems Engineering Vol.3, No.2.

Randell S. Schuler, Susan E. Jackson. 1996. Human Resource Management. Publisher, Jakarta. 1999. Human Resources Management Facing the 21st Century, Jakarta: Issue to six. Volume 2.

Rashid, M. Ryaas. Meaning 1997. Government. Jakarta: YarsifWatampone.

Riduwan, K. 2007. Engkos A Path Analysis. Bandung: Alfabeta

Samaunsamadikun (Prof. Dr.), Seminar on Impact of Globalization and Development of Information Technology in Indonesia. Jakarta, 26-27 October 1992

Sambas Ali Muhidin, S.Pd, M.Si and Drs. MamanAbdurahman, M.Pd. 2007. Correlation Analysis, Regression, and Path In Research. Bandung: PT. Faithful Reader ,.

Simanjuntak Payaman, J.2002. Human Resources Management, Jakarta: Graduate, Unkris.

SinggihSantoso. 2010. nonparametric statistics. Concepts and Applications with SPSS. Jakarta: PT. Elek Media Komputindo.

Sondra P. Siagian.2003. Development Administration. Jaklarta, PT. Earth Literacy. 2004. Human Resource Management, Jakarta, PT. Earth Literacy. 
SoewarnoHandayaningrat. 1996. Introduction to Public Administration and Management, Jakarta: PT. GunungAgung, cet. Number 1

Steers, M. Richard. 1980. Organizational Effectiveness (Rule fairy behavior), the publisher, Jakarta

Subana and MoersetyoRahadiSudrajat. Education Statistics 2000. Publisher: PustakaSetia Bandung

Sugiyono. 2008. The research methodology Quantitative, Qualitative, and R \& D. Bandung: Alfabeta. CV

Alfabeta.

2012. Quantitative Research Methods, Qualitative and R \& D. Bandung:

, 2011. Quantitative Research Methods, Qualitative and R \& D. Bandung: AFABETA, cv.

2013. Methods of quantitative research, qualitative and R \& D.

Bandung: Alfabeta.CV

Sujianto, AE2009. Applications of Statistics with SPSS 16. Jakarta: PT. Pustakarya achievement.

Sukmadinata, NS 2010. Education Research Methods. PT Youth Rosdakarya: Bandung.

Supriyanto.2009. Business Research Methodology, Jakarta: PT. Index.

Surianingrat. 1992. Government Management, Jakarta: PT. Earth Literacy.

Suryamin, Monday, 06/05/2013 Press Release. The Central Statistics Agency (BPS), Jalan Dr.

Sutomo. Jakarta. bisniskeuangan.kompas.com/www.bps.go.id/?news=1010

Susanti, E. 2013. The qualitative research.Social research methods. Jakarta: Kencana

TaufikHudayat and Nina Istiadah. 2011. The Complete Guide to Mastering SPSS 19 for data processing siatistik research, Jakarta: PT. TransMedia.

Thoha, Miftah. 2001. Leadership in Management, Jakarta: Rajawali Pers.

TiktikSartikaPartomo. 2008. Industrial Economics, Jakarta: Inti Prima.

Turban, McLean, Wetherbe. 1996. Information Technology for Management Improving Quality and Productivity, John Wiley \& Sons, Inc.

Roes WigrantoroSetiyadi. Paradigm Seminar 2003. Good governance in the Information Age Competitive, Democratic and Transparent, Gunadarma University Jakarta,

Winardi J. 2007. Motivation and motivating in Management, Jakarta: PT. King GrafindoPersada. 
Vol-3, Issue-4, 2019 (IJEBAR)

\section{E-ISSN: 2614-1280 P-ISSN 2622-4771}

http://jurnal.stie-aas.ac.id/index.php/IJEBAR

Winardi J. 2007. Motivation and motivating in Management, Jakarta: PT. King GrafindoPersada.

John Whitmore. 1997. Coaching for Performance, Art directing for Boosting Performance, Jakarta. PT. GramediaPustakaUtama.

Law Number 20 Year 2008 on Micro, Small and Medium Enterprises.

Law Number 32 Year 2004 on Regional Government. Affirming that regional governments are given the opportunity to organize and manage all potential available resources.

Indonesian Presidential Regulation No. 28 Year 2008 on the National Industrial Policy

Regulation of the Minister of Administrative Reform and Bureaucratic Reform Apartur Republic of Indonesia Number 25 of 2012. Enacted in Jakarta On May 7, 2012 and enacted on June $8,2012$.

Regulation of the Minister of Industry No. 27 / M-IND / PER / 7/2017 year 2017 on Growth and Development of Small and Medium Industries

Regulation of the Minister of Industry Number. 105 / M-IND / PER / 10/2010 On the Organization and Administration of the Ministry of Industry. Establishment of a new organizational structure of the Ministry of Industry

Ministerial Decree No. 78 of 2007 on Improving Effectiveness of Small and Medium Industry Development Approach One Village One Product (One Village One Product-OVOP) Sentra

Regulation of the Director General of Small and Medium Enterprises No. 01 / IKM / PER / I / 2013 Date January 3, 2012 on Guidelines for Management of Budget Implementation List (DIPA)

Performance Plan of the Ministry of Industry in 2014. The General Secretariat of the Planning Bureau, 2013, Jakarta.

Strategic Plan: Revitalization and growth of Small and Medium Industry 2010-2014. 